\title{
Exploring genes of rectal cancer for new treatments based on protein interaction network
}

\author{
Running Title:protein interaction network of rectal cancer \\ Wenjing Teng ${ }^{1}$, Chao Zhou ${ }^{2}$, , Yan $\mathrm{Li}^{1 *}$
}

1.Department of oncology, Shanghai Municipal Hospital of Traditional Chinese

Medicine ,Affiliated to Shanghai University of Traditional Chinese Medicine, Zhijiang road 274 , Shanghai 200041, China.2.Department of oncology, Weifang Traditional Chinese Medicine Hospital,Kuiwen District, Weifang , Shandong Province 261041, China;

*Corresponding author: E-mail : 18916767226@163.com.

Abstract

Objective: To develop a protein-protein interaction network of rectal cancer, which is based on genetic genes as well as to predict biological pathways underlying the molecular complexes in the network. In order to analyze and summarize genetic markers related to diagnosis and prognosis of rectal cancer.

Methods: the genes expression profile was downloaded from OMIM (Online Mendelian Inheritance in Man) database; the protein-protein interaction network of rectal cancer was established by Cytoscape; the molecular complexes in the network were detected by Clusterviz plugin and the pathways enrichment of molecular complexes were performed by DAVID online and Bingo (The Biological Networks Gene Ontology tool).

Results and Discussion: A total of 127 rectal cancer genes were identified to differentially express in OMIM Database. The protein-protein interaction network of rectal cancer was contained 966 nodes (proteins), 3377 edges (interactive relationships) and 7 molecular complexes (score>7.0). Regulatory effects of genes and proteins were focused on cell cycle, transcription regulation and cellular protein metabolic process. Genes of DDK1, sparcl1, wisp2, cuxl, pabpc1, ptk2 and htra1 were significant nodes in PPI network. The discovery of featured genes which were probably related to rectal cancer, has a great significance on studying mechanism, distinguishing normal and cancer tissues, and exploring new treatments for rectal cancer.

Keywords: Protein-protein interaction networks; rectal cancer; molecular complexes; pathway , 
genes

Rectal cancer is one of the common fatal malignant tumors in the world, which is secondly lethal cancer in United States as well as thirdly in Europe. The research has improved systemic treatment, such as micro diagnosis. However, despite advances in detection and care, morbidity and mortality from rectal cancer continues to be high[1].Early detection and diagnosis can be great significance to reduce mortality and improve prognosis, as well as identify those who were at the highest risk duo to improving triage for treatment has the greatest impact on rectal cancers treatment. Studies shown that rectal cancer has a prime paradigm for cancer genetics, which can be prevention by early detection of the pre-disease (neoplastic) state. Therefore, the roles of genetics in rectal cancer have became critical to the missions of disease prevention, early detection and effective treatment.

As report goes, approximately $10 \%$ of well defined hereditary rectal cancer has syndromes[2]. Hereditary rectal has some benefits, such as many of it are growing slowly, family members are armed with the knowledge of potential risk of associated carcinomas and empowerment to reduce the disease burden.

A large number of mutation, mismatch, inactivation of tumor suppressor genes and activations of oncogenes are involved in the process of rectal cancer[4].Up to now, genetic marker of rectal cancer can be summarized by the following six aspects : genomic instability, CpG island methylator phenotype, specific microRNAs, histone modification, gene mutation and protein biomarkers. The protein-protein interaction network which is a model of biological molecular interactions can more clearly show the genes, proteins and pathogenesis in the development process of the disease[5]. These genetic traits may partially explain the geographical variance in rectal cancer incidence and mortality as well as the differences between hereditary and sporadic rectal cancer [6]. 


\section{Materials and Methods}

\section{Design: Study on enrichment of genomic biological pathways.}

\section{Method:}

Data acquisition: OMIM(Online Mendelian Inheritance in Man) is a comprehensive, authoritative, daily updated human phenotype database, containing more than 12000 genes of all human genetic diseases, and mainly focusing on hereditary diseases. In addition, text messages, related reference information, sequence records, maps, and related databases are available for each gene[7-8]. This study had started from August 22(2015), searched "rectal cancer"in the OMIM database and obtained human genes associated with rectal cancer information.

The construction of gene/protein interaction networks: rectal cancer associated genes were submitted to Cytoscape 3.2.1 plug-in Agilent Literature Search 2.7.7 (USA Agilent Technologies company) and Pubmed [9]. False positive interaction information was removed from retrieval results. Then, gene/protein interaction relations were read in Cytoscape 2.8.2 and visualized [10].

Network analysis: MODE algorithm in Cytoscape 3.2.1 web analytics plug-in Clusterviz of 1.2 was administrated to make the correlation analysis for the area of the construction of biological networks [11-12]. By analyzing the network structure, proteins were grouped to form molecular compounds in the entire network and were shown in Cytoscape according to the correlation integral value. The areas with integral value higher than 3 were regarded as molecular compounds. The gene/protein names contained in the molecular compounds were submitted to The Database for Annotation, Visualization and Integrated Discovery. [13-14] By retrieving Kyoko Encyclopedia of Genes and Genomes (KEGG) Database, biological pathways involved in chronic myelogenous leukaemia heredity were identified. Then the Biological pathways data were submitted to Bingo (in Networks Gene Ontology tool) for enrichment analysis.

Main outcome measures: Protein networks were constructed based on the rectal cancer-related genes, nodes (proteins) and edges (interaction between), molecular complexes in the network and its associated interaction points and nodes (protein) and the edge (interaction between), analyze the biological pathways has involved in the molecular complexes.

\section{Results}




\subsection{Rectal cancer related genes in OMIM}

According the OMIM database retrieval, it can found that 127 genes were reported to be associated with rectal cancer. After screening and deleting duplicate genes, 127 related genes were identified, which shown in Table1.

\subsection{Protein interaction networks}

Through text mining,127 genetic-related genes shown that there was a network diagram with 638 nodes (proteins) and 1830 edges. As shown in Figure 1-3, the diamond is represented OMIM genetic disease related proteins, while the round represented the proteins obtained from text mining.

\section{Figure 1(A+B). Network map of protein interaction (Overall )}

As shown in figure 1, the protein-protein interaction network underlining rectal cancer is extremely complex. The edges intersect with each other and several clusters emerge in the figure. The more edges among the genes, the correlation of the genes is more tightening. So the genes formed the round network at the top of figure 1 connected with each other more tightly than the genes in the bottom.

\section{Figure 2 the relationship of proteins}

After removing the protein molecule in the network, the relationship between proteins in network became more clear, in the centre part of protein-protein network, the relationship between protein complexes emerged is closer, however, at the farther edge of the network, the relationship of it became looser, as shown in Figure2. 
Figure 3(A): pathway jak2-stat1

\section{Figure 3(B): relationship of gene Kras}

AS shown in Figure3, it can be found some common genes and pathways such as jak2-stat1,Kras, $\mathrm{P} 53$,etc as well as genes associated with them.

\subsection{Network topology attribute analysis}

Network topology attribute analysis shown that the connectivity of nodes in the network (the number of nodes in the network ) obeys descending distribution, i.e. with the increase of edges connected to the node, correspondingly the number of nodes decrease, so it can be seen that the gene - protein interaction networks are scale-free networks [15]. We found that the connectivity of nodes in the network greater than or equal to 25 corresponds to a sharp reduction in the number of nodes Figure 4. Therefore, we regarded the nodes which the connectivity is greater than / equal to 20 as the key nodes (hub). Key nodes (connectivity score)included :hif1a(25), cdkn1b(25), rb1(26), plau(26), brca1(27), asns(28), pcna(28),Vegfa(29), stat1(29), cdkn2a(29), egfr(30), tp53(71).

\section{Figure 4. Connectivity degree of each node and betweenness Comparison}

(The horizontal axis represents between ness, and the ordinate represents the connectivity degree of protein interaction network. And the graphic in the table represents each node in the network). It can be seen that the connectivity (the number of nodes in the network ) of nodes in the network obeys descending distribution, while the connectivity is greater than / equal to 25 , the number of nodes corresponding to a sharp decrease.

\subsection{The detection of molecular complexes}

According MCOMD algorithm analysis, analyse the correlation between genes in network and calculate the score, the number of nodes, the number of edges. There is a total of 74 molecular complexes and 7 of them showed correlation integral values higher than7.0. 


\title{
Figure 5.
}

\author{
Rank1 score20 Node20 Edges190 \\ Rank2 score20 Node20 Edges190 \\ Rank3 score14 Node14 Edges91 \\ Rank4 score11.662 Node78 Edges449 \\ Rank5 score3.143 Node21 Edges66 \\ Rank6 score9 Node9 Edges36 \\ $\begin{array}{llll}\text { Rank7 } & \text { score7.673 Node56 } & \text { Edges221 }\end{array}$
}

Figure 5 Molecular complexes obtained by MCOMD algorithm analysis

The details of the relationship of proteins in molecular complexes 7 was shown in Figure 6

Figure6 the relationship of proteins in molecular complexes 7

The whole network has a total of six parts, including mitogen-activated protein kinase, Specific microRNAs, SRY-related HMG-box, matrix metalloproteinases, cyclinD.

\subsection{Molecular complex pathway enrichment}

Submit the 7 names of protein molecule complexes online to obtain the relevant pathways in

Table 2.The Protein molecule biological pathways of complexes 1 are not exist,and other complexes contain different pathways.Regulatory effects of genes and proteins mainly focused on cell cycle, transcription regulation, and cellular protein metabolic process.

Table 2 Enrichment of pathways related to molecular complexes 
Binggo results show the gene oncology hierarchical network to the biological processes,Figure 7.The size of the node represents the number of the genes, the depth of the node color represents the $\mathrm{P}$ values.Diagrams have presented the main biological processes of cluster2,3,5,containing metabolic regulation, transcriptional regulation, biosynthesis, cell differentiation and gene expression regulation and signal transduction, etc.

\section{Figure7}

\section{A Bingo results show that the basic structure of the biological cluster1 \\ B Bingo results show that the basic structure of the biological cluster4 \\ C Bingo results show that the basic structure of the biological cluster6 \\ C Bingo results show that the basic structure of the biological cluster7}

\section{Discussions}

Based on a large number of research references, the progression of rectal cancer is a multistep process, containing overcome apoptosis, inhibiting senescence (infinite proliferation), secretion proliferation signal itself, not sensitive to growth signals, angiogenesis and invasion , which requires a large number of genes and proteins in action[16].Genetic markers of rectal cancer can be summarized from the following six aspects :he first part is genomic instability, close to $12-17 \%$ of sporadic rectal cancer cases exist with microsatellite instability (MSI). At present, microsatellite instability - high - H (MSI) has become a positive prognosis of rectal cancer patients' overall survival[17]. 50-85\% of Rectal cancer patients has chromosome aberration frequency, chromosome instability (CIN +) usually be associated with colorectal cancer patients' overall survival, progression-free survival (PFS) and poor prognosis after 5 - fluorouracil therapy; the second part is CpG island methylator phenotype. Nearly $29.6 \%$ of the rectal cancer patients shown CpG island methylation phenotype - high (CIMP - H) [18], however, its value is still in research. Specific microRNAs and histone modification are another two aspects, which mainly associate with colorectal cancer patients' overall survival and progression-free serial, tumor metastasis, local 
invasion, tumor volume, tumor staging, treatment results, relapse and drug resistance.

What is more, gene mutations and protein biomarkers have brought a special significance. The APC gene mutant p.D1822V containing homozygous V/V would reduce the risk of rectal cancer[19]. According to the APC (rs565453 y rs1816769) and CTNNB1 (rs229303) gene polymorphisms, the death risk stratification in patients with rectal cancer can be analysed. The APC gene mutant p.I1307K as risk factors of the rectal cancer among Ashkenazi Jewishes has been found[20]. The loss of PTEN gene in $22 \%$ of rectal cancer patients has caused no response to the EGFR inhibitors and higher risk of death [21]. And the clinical application of protein molecular markers colorectal cancer mainly included: early diagnosis(hnRNP A1, kininogen-1, adipophilin, Apo AI and C9,OLFM4), Prognosis(SM3,desmin,surviving,hTERT and NM23), Potential therapeutic targets(EB1)[22-23]. Therefore, exploring the protein interaction network of tumors, analysing the characteristics of the protein molecular interaction network, and excavating a variety of signalling pathway and the genes will provide a biological basis for the study of the molecular mechanism of tumor and the further treatment as well.

Bio-molecular network analysis is an important direction of systematic biology research. Large-scale human protein-protein network can provide new insights into protein functions, pathways, molecular machines and functional protein modules [24]. The function of bio-molecular often depends on modularization, the network module is made by a number of nodes in the conjunction of each other and has a stable structure which can often reflect a similar nature between the nodes $[25,26]$. Analysing the function module is the one of the most common method to analyse biological molecular network. According to 127 genes provided by OMIM, our research has built up protein interaction network of rectal cancer, which contain 996 nodes (proteins), 3377 edges (interaction). Due to the network is very large, the experimental introduced MCOMD algorithm to evaluate the network 's regional integration through the correlation integral. Correlation integral descripted the proteins associated with the degree in the region. Proteins of the same molecular complex generally have the same biological function, therefore we can discover the unknown gene functions or new molecular functional groups, such as cluster 1. 
cluster1(score 20) in the centre, have closely relationships with each other as well as other genes. It has reported that the secreted protein acidic and rich in cysteine-like 1 (,sparcll) is expressed in various normal tissues and many types of cancers. Another study has shown that marker sparcll was significantly related to the prognosis and clinical pathological features of the CRC patients [27]. Sparcll expression increased with RT and is related to a better prognosis in rectal cancer patients with RT but not in patients without RT. This result may help us to select the patients to the best suited preoperative RT. In the process of rectal cancer, gene WISP2 knockout significantly increased Caco-2 cell invasion and motility. Up-regulation of MMP2, -7 and -9 may indicate that WISP2regulates invasion and motility through MMPs. Regulation of invasion by WISP2 may involve the WNT signalling pathway[28]. Thus, some studies have identified CUX1 as a pan-driver of tumorigenesis and uncover a potential strategy for treating CUX1-mutant tumors. So from cluster1 we predict the effect of gene Cut1 to rectal cancer may be that CUX1 deficiency activates phosphoinositide 3-kinase (PI3K) signalling through direct transcriptional downregulation of the PI3K inhibitor PIK3IP1 (phosphoinositide-3-kinase interacting protein 1), leading to increased tumor growth and susceptibility to PI3K-AKT inhibition. And we also can forecast a few clones existing in colorectal cancer, containing gene mutation of ptk2, htra1 and

\section{PABPC1.}

Rectal cancer is demonstrated not simply controlled by a particular gene or signaling pathways, but also by the complex process of network system co-ordinately regulated which consisted of a variety of signalling pathways and multiple genes. In the signalling network, it is likely there is some " key regulatory point". At last, a best understanding of chemotherapy molecular targets allowed the identification of genetic markers that can predict the response and/or the toxicity of anti-cancer drugs used in rectal cancers, which could be helpful in the future to propose for each patient a personalized treatment [29-31]. Mutations that can predict the response of new target therapies such as the inhibitors of the JAK kinase inhibitor AG4 90 in colorectal cancer have also been found and will allow the selection of patients who can have benefit from these new therapeutic drugs. The experiment dig out a variety of signalling pathways and genes which can provide reliable directions for molecular mechanism research of treatment, and it need to be further verified. 


\section{Compliance with Ethical Standards}

Conflict of interest : We declare that we have no financial and personal relationships with other people or organizations that can inappropriately influence our work, there is no professional or other personal interest of any nature or kind in any product, service and/or company that could be construed as influencing the position presented in, or the review of, the manuscript entitled exploring genes of rectal cancer for new treatments based on protein interaction network

Ethical approval: This article does not contain any studies with human participants or animals performed by any of the authors.

\section{References}

1. Spreadborough P, Doran C.The current thinking on colorectal cancer.J R Nav Med Serv 2015;101(1):47-54.

2. Stoffel EM, Boland CR.Genetics and Genetic Testing in Hereditary Colorectal Cancer.

Gastroenterology 2015;pii:S0016-5085(15)01016-1.

3. Schlemper RJ,Dawsey SM,Itabashi M,et al. Differences in diagnostic criteria for esophageal squamous cell carcinoma between Japanese and Western pathologists.Cancer 2000 ;88(5):996-1 006.

4. Schlussel AT1, Gagliano RA Jr1, Seto-Donlon S1.The evolution of colorectal cancer geneti cs-Part 1: from discov ery to practice. J Gastrointest Oncol. 2014 ;5(5):326-35.

5. Zhou C1, Teng WJ, Yang J,et al.Construction of a protein-protein interaction network for chronic myelocytic leukemia and pathway prediction of molecular complexes.Asian Pac J Cancer Prev 2014;15(13):5325-30.

6. Macaron C1, Heald B, Burke CA,et al.Using Genetics to Identify Hereditary Colorectal Polypo sis and Cancer Syndromes in Your Patient.Curr Gastroenterol Rep 2015 ;17(10):463.

7. Hamosh A, Scott AF, Amberger JS, et al. Online Mendelian Inheritance in Man (OMIM), a 
knowledgebase of human genesand genetic disorders. Nucleic Acids Res 2005;33(Database issue):D514-517.

8. Amberger J, Bocchini CA, Scott AF, et al. McKusick's Online Mendelian Inheritance in Man (OMIM). Nucleic Acids Res 2009;37(Database issue):D793-796.

9. Vailaya A, Bluvas P, Kincaid R, et al. An architecture for biological information extraction and representation.Bioinformatics 2005;21 (4):430-438.

10. Shannon P, Markiel A, Ozier O, et al. Cytoscape: a software environment for integrated models of biomolecular interaction networks. Genome Res 2003;13(11):2498-2504.

11. Chen L, Wang H, Zhang L, et al . Uncovering packaging features of co-regulated modules based on human protein interaction and transcriptional regulatory networks. BMC Bioinformatics, $2010 ; 11: 392$.

12. Wu BL,Zhou HY,Lv GQ, et al. Protein-protein Interaction network analyses for elucidating the roles of LOXL2-delta72 in esophageal squamous cell carcinoma. Asian Pac J Cancer Prev 2014;15(5): 2345-51.

13. Dennis G Jr, Sherman BT, Hosack DA, et al. DAVID: Database for Annotation, Visualization, and Integrated Discovery[J]. Genome Biol 2003;4(5):P3.

14. Huang da W, Sherman BT, Lempicki RA. Systematic and integrative analysis of large gene lists using DAVID bioinformatics resources. Nat Protoc 2009;4(1):44-57.

15. Burkard TR, Rix U, Breitwieser FP, Superti-Furga G, Colinge J. A computational approach to analyze the mechanism of action of the kinase inhibitor bafetinib[J].PLoS Comput Biol 2010;6(11):e1001001.

16. Smolle MA1,2, Pichler M1, Haybaeck J2,et al. Genetic markers of recurrence in colorectal cancer. Pharmacogenomics. 2015; 12:1-14.

17. Bacher JW1, Sievers CK2, Albrecht DM3, et al.Improved Detection of Microsatellite Instability in Early Colorectal Lesions.PLoS One 2015 7;10(8):e0132727. 
18. Lee DW, Han SW, Cha Y, Rhee YY, et al.Different prognostic effect of CpG island methylation according to sex in colorectal cancer patients treated with adjuvant FOLFOX.

Clin Epigenetics 2015;7(1):63.

19. Guerreiro CS1, Cravo ML, Brito M, Vidal PM,et al .The D1822V APC polym orphism interacts with fat, calcium, and fiber intakes in modulating the risk of colorectalcancer in Portugues e persons.Am J Clin Nutr 2007;85(6):1592-7.

20. Stern HS1, Viertelhausen S, Hunter AG, et al. APC I1307K increases risk of transition from polyp to colorectal carcinoma in Ashkenazi Jews.Gastroenterology 2001;120(2):392-400.

21. Mao C1, Zhou J, Yang Z, Huang Y,et al.KRAS,BRAF and PIK3CA mutations and the 1 oss of PTEN expression in Chinese patients with colorectal cancer.PLoS One 2012;7(5):e36653.

22. Cappellani A1, Di Vita M, Zanghi A, et al. Biological and clinical markers in colorectal cancer: state of the art.Front Biosci (Schol Ed) 2010;2:422-31.

23. Delektorskaya VV1, Golovkov DA, Kushlinskii NE.Clinical significance of levels of molecular biological markers in zones of invasive front-line of colorectal cancer.Bull Exp Biol Med 2008;146(5):616-9.

24. Ryu JY1, Kim HU, Lee SY. Human genes with a greater number of transcript variants tend to show biological features of housekeeping and essential genes.Mol Biosyst 2015 Aug 17. [Epub ahead of print]

25. Chen L,Wang H,Zhang L,et,al.Uncovering packaging features of co-regulated modules based on human protein interaction and transcriptional regulatory networks[J].BMC Bioinformatics 2010;7(11):392.

26. Kovács IA, Palotai R, Szalay MS,et,al. Community Landscapes: An Integrative Approach to Determine Overlapping Network Module Hierarchy,Identify Key Nodes and Predict Network Dynamics[J].PLoS One 2010;5(9): e12528.

27. Yu SJ1, Yu JK, Ge WT, et al. SPARCL1, Shp2, MSH2, E-cadherin, p53, ADCY-2 and M 
APK are prognosis-related in colorectal cancer.World J Gastroenterol 2011;17(15):2028-36.

28. Frewer KA1, Sanders AJ, Owen S, et al.A role for WISP2 in colorectal cancer cell invasion and motility.Cancer Genomics Proteomics 2013;10(4):187-96.

29. Gho Kwang-,Cusick M E,Valle D,et al.The human diseases net work. P Natl Acad Sci USA 2007;104(21):8685-90.

30. Yildirim M A,Goh K I,Cusick M E,et al.Drug-target network. Nat Biotechnol 2007;25(1 $0): 1119-26$.

31. Hopkins A L.Network pharmacology:the next paradigm in drug discovery. Nat Chen Biol 2008,4(11):682-90. 

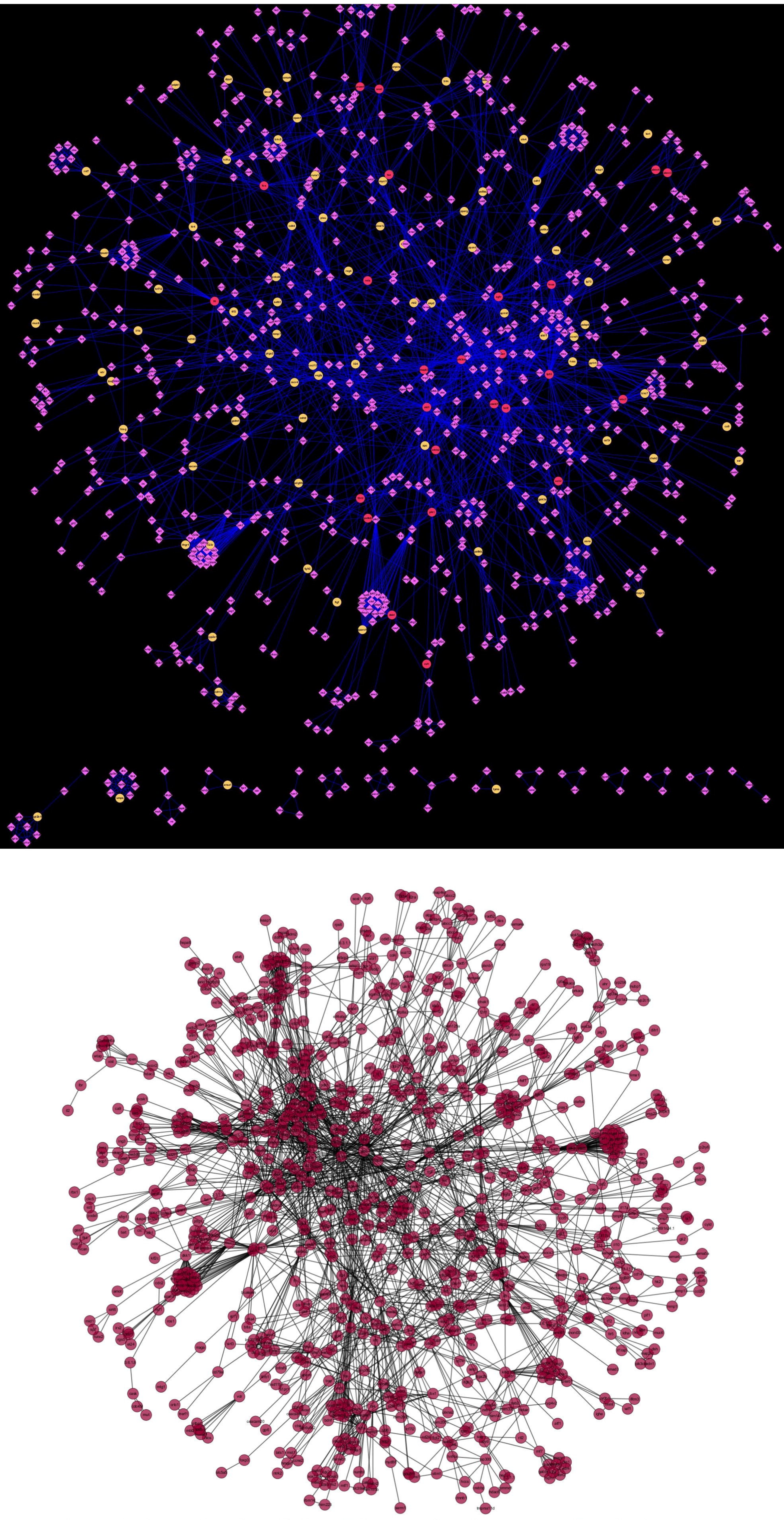

둥

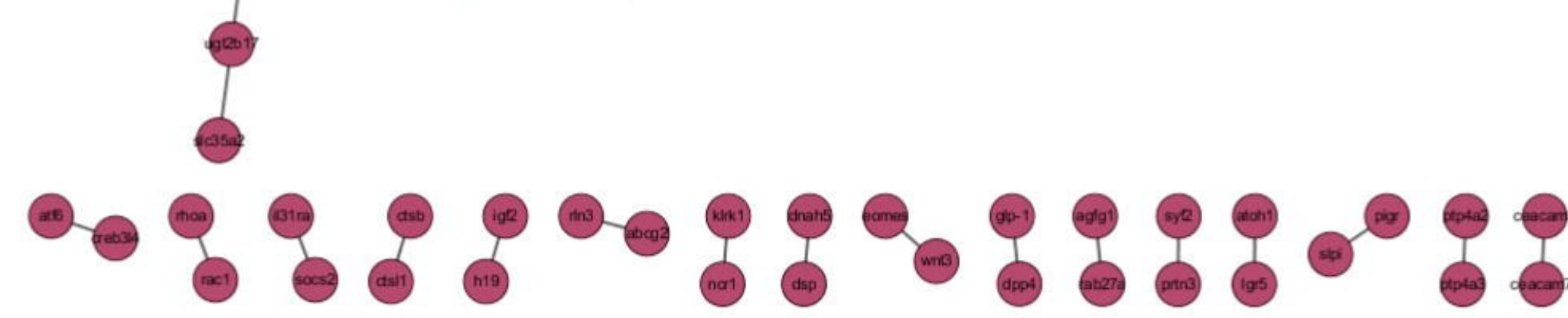




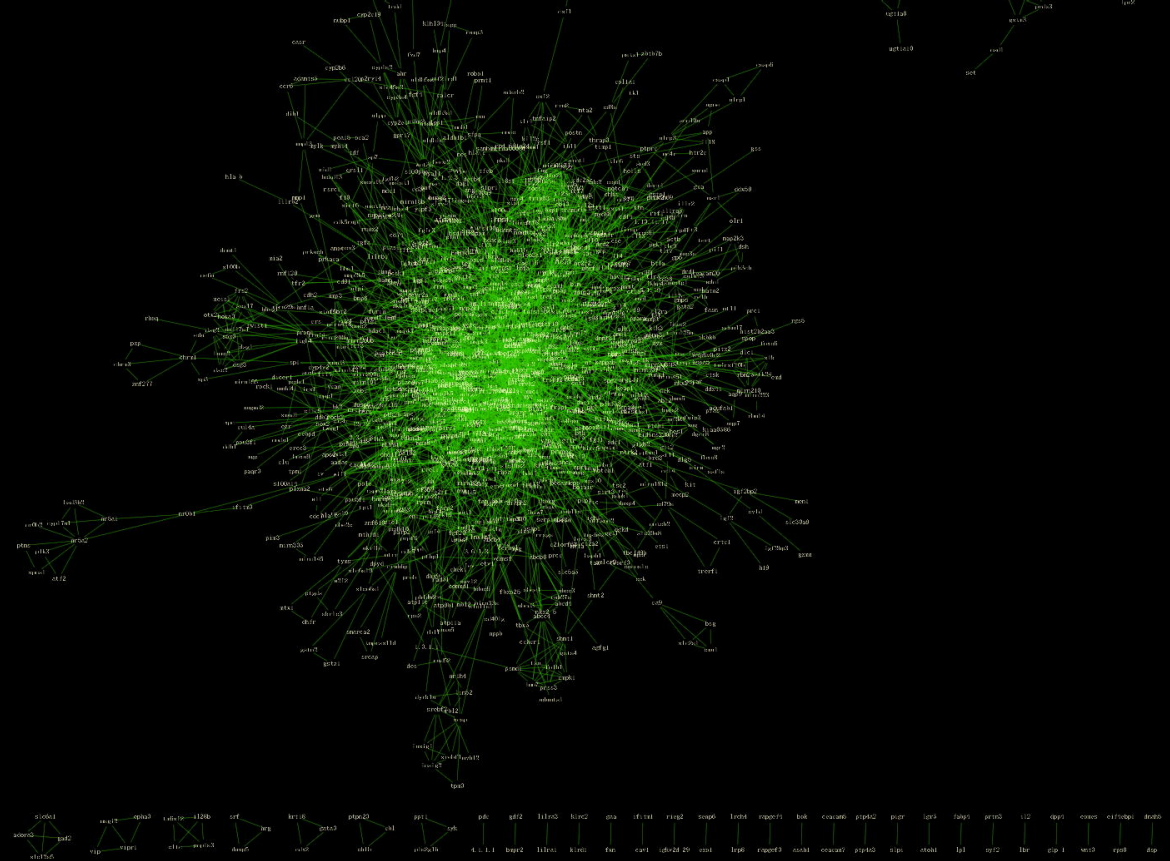

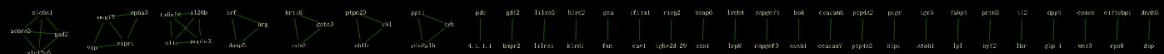




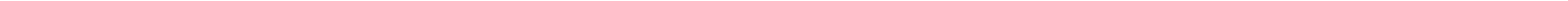




\section{Centiscape Scatter Plot view}

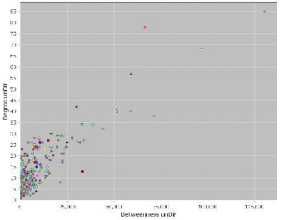




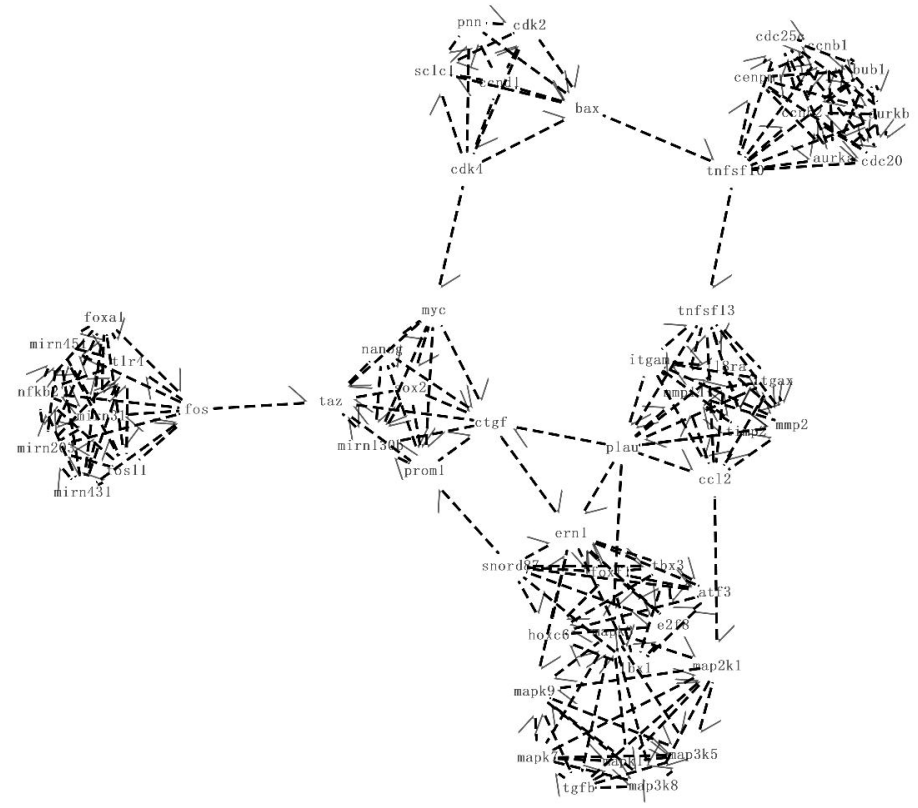




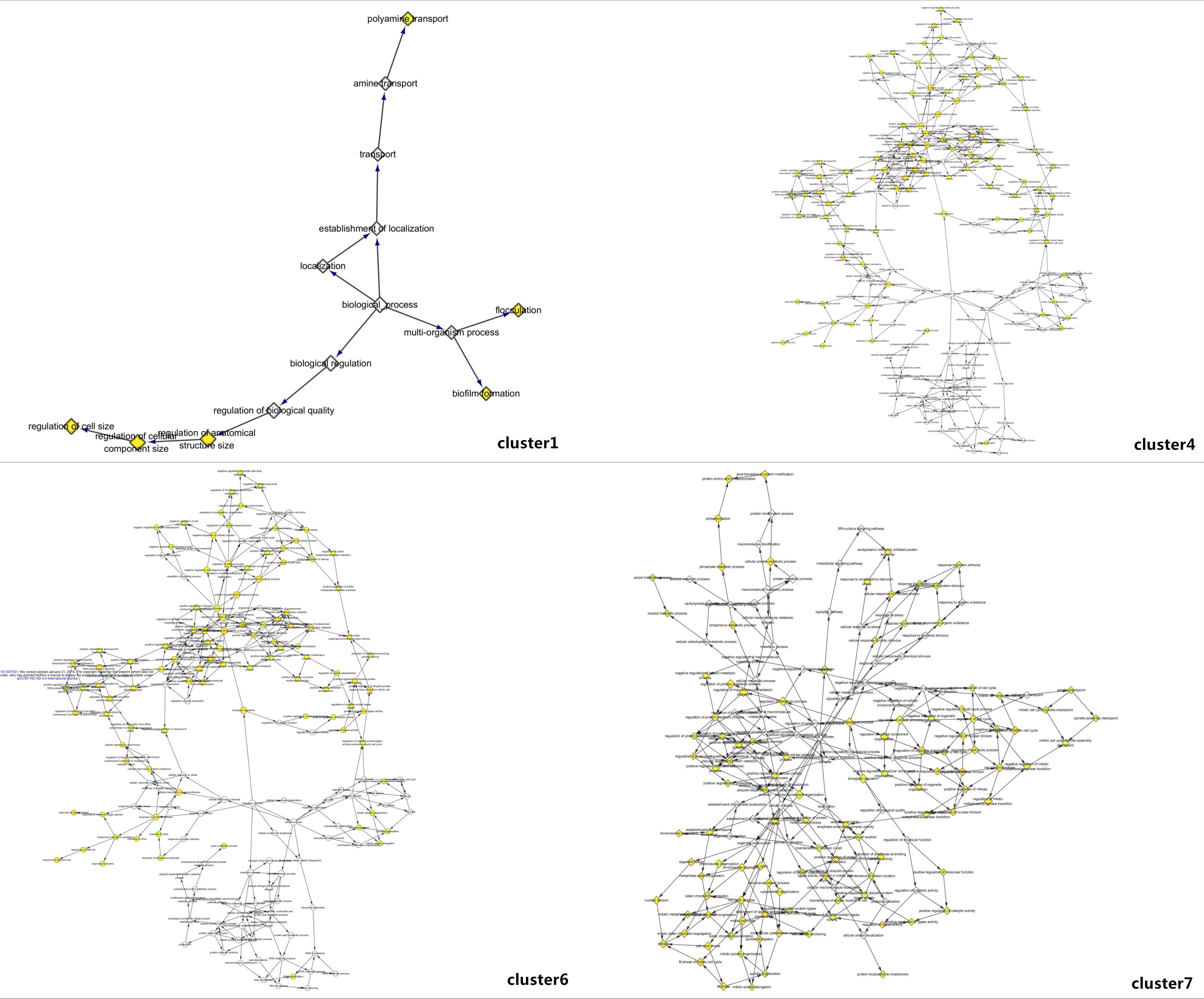




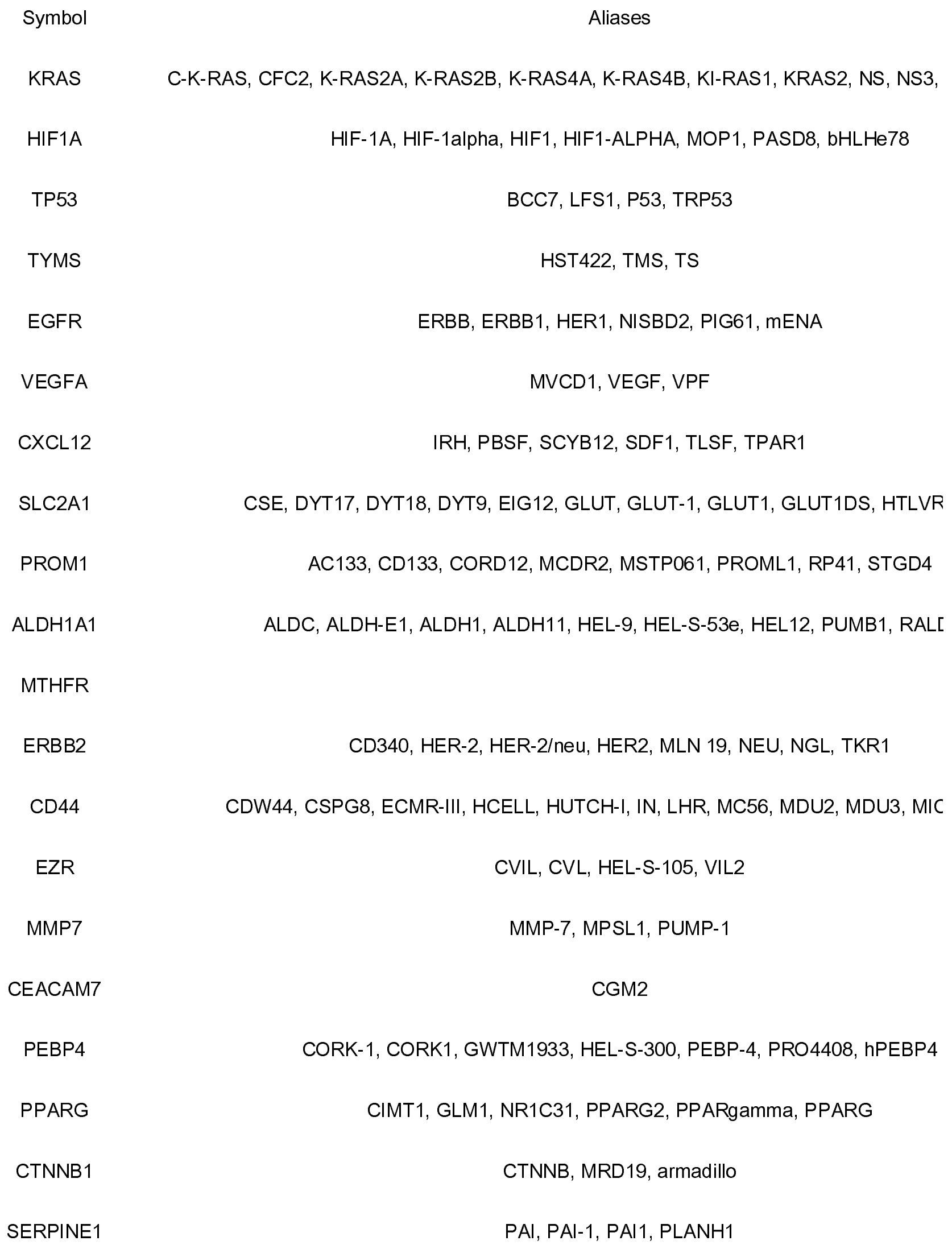


BIRC5

$\mathrm{XRCC} 1$

PIK3CA

HRAS

CYP2E1

$\mathrm{EZH} 2$

MKI67

CA9

CEACAM1

DPYD

TGFA

CEACAM5

PDPK1

LGR5

ETV4

APOE

IL6

TGFB1

PTGS2

CRP

IL1B
API4, EPR-1

$\mathrm{RCC}$

CLOVE, CWS5, MCAP, MCM, MCMTC, PI3K, p110-alpha

C-BAS/HAS, C-H-RAS, C-HA-RAS1, CTLO, H-RASIDX, HAMSV1, RASH1, p21ras

CPE1, CYP2E, P450-J, P450C2E

ENX-1, ENX1, EZH1b, KMT6, KMT6A, WVS, WVS2, EZH2

KIA, MIB-, MIB-1, PPP1R105

CAIX, MN

BGP, BGP1, BGPI

DHP, DHPDHASE, DPD

TFGA

CD66e, CEA

PDK1, PDPK2, PDPK2P, PRO0461

FEX, GPR49, GPR67, GRP49, HG38

E1A-F, E1AF, PEA3, PEAS3

AD2, APO-E, LDLCQ5, LPG

BSF2, HGF, HSF, IFNB2, IL-6

CED, DPD1, LAP, TGFB, TGFbeta

COX-2, COX2, GRIPGHS, PGG/HS, PGHS-2, PHS-2, hCox-2

PTX1

IL-1, IL1-BETA, IL1F2 
AKT1

VDR

TLR4

GSTM1

PTEN

$\mathrm{CDH} 1$

TERT

BCL2

CCND1

HLA-DQB1

RELA

CASP3

HLA-G

MAPK3

MMP1

APC

CYP19A1

ERCC2
AKT, CWS6, PKB, PKB-ALPHA, PRKBA, RAC, RAC-ALPHA

NR1I1, PPP1R163

ARMD10, CD284, TLR-4, TOLL

GST1-1, GSTM1a-1a, GSTM1b-1b, GTH4, GTM1, H-B, MU, MU-1, GSTM1

10q23del, BZS, CWS1, DEC, GLM2, MHAM, MMAC11, TEP1, PTEN

Arc-1, CD324, CDHE, ECAD, LCAM, UVO

CMM9, DKCA2, DKCB4, EST2, PFBMFT1, TCS1, TP2, TRT, hEST2, hTRT

Bcl-2, PPP1R50

CD184, D2S201E, FB22, HM89, HSY3RR, LAP-3, LAP3, LCR1, LESTR, NPY3R, NPYR, NPYF

\section{WHIMS}

BCL1, D11S287E, PRAD1, U21B31

CELIAC1, HLA-DQB, IDDM1

NFKB3, p65

CPP32, CPP32B, SCA-1

MHC-G

TCF7L2

TCF-4, TCF4 
F3

TP73

LCN2

RUNX1

FGFR2

CHEK2

PLAU

TIMP1

RAD51

PLK1

POU5F1

$\mathrm{XRCC3}$

SOX2

PDGFRB

STK11

DKK1

EPAS1

AML1, AML1-EVI-1, AMLCR1, CBF2alpha, CBFA2, EVI-1, PEBP2aB, PEBP2a BBDS, BEK, BFR-1, CD332, CEK3, CFD1, ECT1, JWS, K-SAM, KGFR, TK14, 1 CDS1, CHK2, HuCds1, LFS2, PP1425, RAD53, hCds1

ATF, BDPLT5, QPD, UPA, URK, u-PA

CLGI, EPA, EPO, HCI, TIMP

BRCC5, FANCR, HRAD51, HsRad51, HsT16930, MRMV2A, RECA, RAD51

PLK, STPK13

OCT3, OCT4, OTF-3, OTF3, OTF4, Oct-3, Oct-4

CMM6

ANOP3, MCOPS3

CD140B, IBGC4, IMF1, JTK12, PDGFR, PDGFR-1, PDGFR1

LKB1, PJS, hLKB1

DKK-1, SK

ECYT4, HIF2A, HLF, MOP2, PASD2, bHLHe73

CASH, CASP8AP1, CLARP, Casper, FLAME, FLAME-1, FLAME1, FLIP, I-FLICE, MRIT, c-FLIF CFLAR C-FLIPS

FOS AP-1, C-FOS, p55

SKP2 FBL1, FBXL1, FLB1, p45 
NRAS

CCNE1

IL23R

PPARD

RPS6KB1

ANXA1

PTGS1

BLM

CD163

SPINK1

CLDN1

PDCD4

IFNGR1

IL24

$\mathrm{ABCC} 4$

ALOX12

BIRC7

SATB1

TFF3

CSF3R

RBL2
ALPS4, CMNS, N-ras, NCMS1, NS6, NRAS

CCNE, pCCNE1

FAAR, NR1C2, NUC1, NUCI, NUCII, PPARB

PS6K, S6K, S6K-beta-1, S6K1, STK14A, p70 S6KA, p70(S6K)-alpha, p70-S6K, p7

ANX1, LPC1

COX1, COX3, PCOX1, PES-1, PGG/HS, PGHS-1, PGHS1, PHS1, PTGHS

BS, RECQ2, RECQL2, RECQL3

M130, MM130

PCTT, PSTI, Spink3, TATI, TCP

CLD1, ILVASC, SEMP1

$\mathrm{H} 731$

CD119, IFNGR, IMD27A, IMD27B

C49A, FISP, IL10B, MDA7, MOB5, ST16

MOAT-B, MOATB, MRP4

12-LOX, 12S-LOX, LOG12

KIAP, LIVIN, ML-IAP, MLIAP, RNF50

ITF, P1B, TFI

CD114, GCSFR

$\mathrm{P} 130, \mathrm{Rb} 2$ 
RPS6KA1

FIGF

TPSAB1

GSK3A

$\mathrm{ABCC} 3$

MIR137

TAZ

UGT2B15

PPP1R13L

REG4

WISP1

ASNS

UMPS

F2RL2

LIMS1

MUC6

RSF1

MYCL

RPS6KB2

RNF7

RPS6KA2
HU-1, MAPKAPK1A, RSK, RSK1, p90Rsk

VEGF-D, VEGFD

TPS1, TPS2, TPSB1

ABC31, EST90757, MLP2, MOAT-D, MRP3, CMOAT2

MIRN137, miR-137

BTHS, CMD3A, EFE, EFE2, G4.5, LVNCX, Taz1

HLUG4, UDPGT 2B8, UDPGT2B15, UDPGTH3, UGT2B8

IASPP, NKIP1, RAI, RAI4

GISP, REG-IV, RELP

CCN4c, WISP1i, WISP1tc, WISP1

ASNSD, TS11

OPRT

PAR-3, PAR3

PINCH, PINCH-1, PINCH1

MUC-6

HBXAP, RSF-1, XAP8, p325

L-Myc, LMYC1, bHLHe38, MYCL

KLS, P70-beta, P70-beta-1, P70-beta-2, S6K-beta2, S6K2, SRK, STK14B, p70(S6K)-be

CKBBP1, ROC2, SAG

HU-2, MAPKAPK1C, RSK, RSK3, S6K-alpha, S6K-alpha2, p90-RSK3, pp90R؟ 
bioRxiv preprint doi: https://doi.org/10.1101/037531; this version posted January 21,2016 . The copyright holder for this preprint (which was not certified by peer review) is the author/funder, who has granted bioRxiv a license to display the preprint in perpetuity. It is made available under aCC-BY-NC-ND 4.0 International license.

SPARCL1

SPEN

SEMA4C

DNAJC12
MAST 9, MAST9, PIG33, SC1

HIAA0929, MINT, RBM15C, SHARP

M-SEMA-F, SEMACL1, SEMAF, SEMAI

JDP1 
bioRxiv preprint doi: https://doi.org/10.1101/037531; this version posted January 21,2016 . The copyright holder for this preprint (which was not certified by peer review) is the author/funder, who has granted bioRxiv a license to display the preprint in perpetuity. It is made available under aCC-BY-NC-ND 4.0 International license.

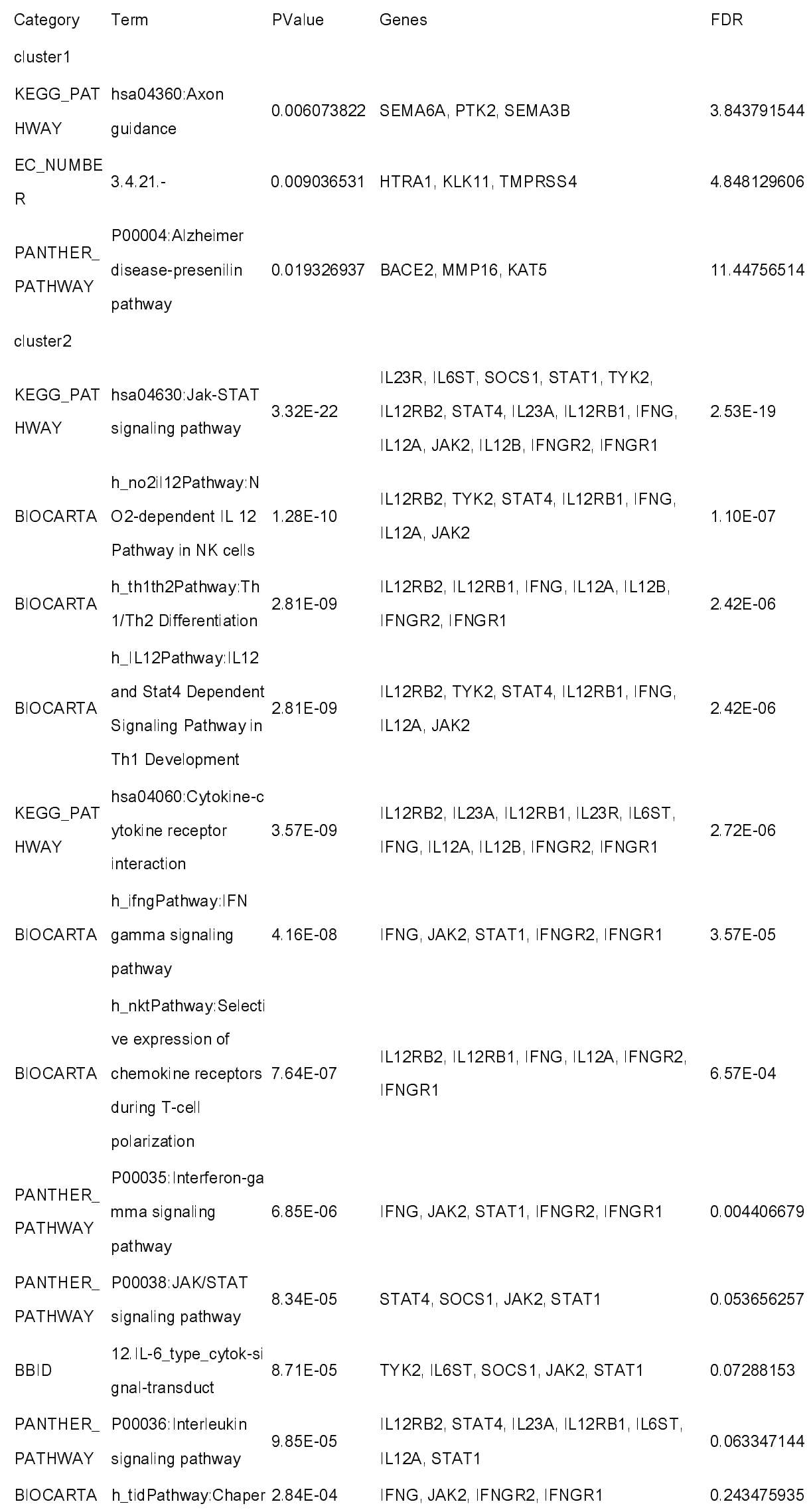




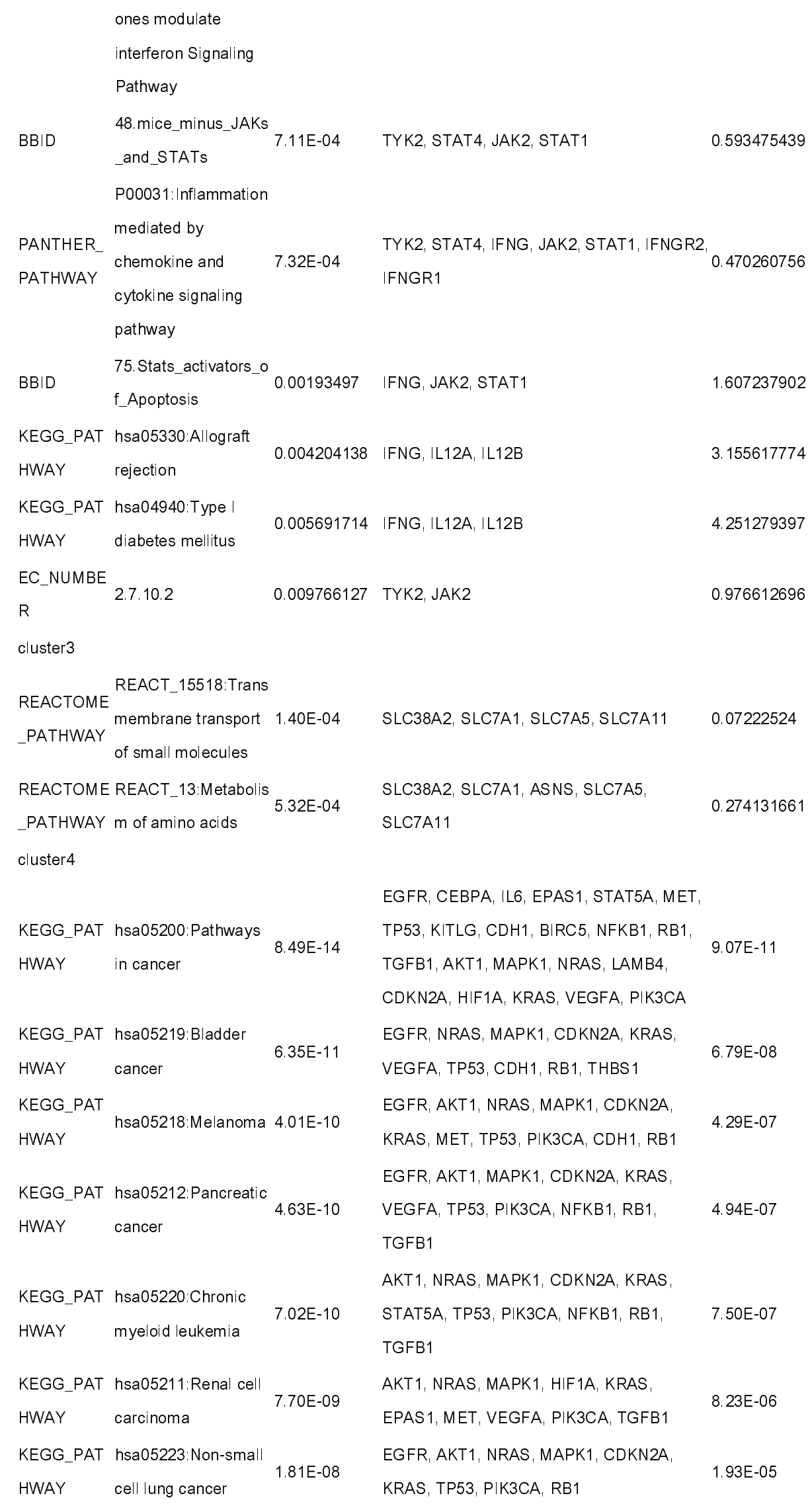




\begin{tabular}{|c|c|c|c|c|}
\hline $\begin{array}{l}\text { KEGG_PAT } \\
\text { HWAY }\end{array}$ & hsa05214:Glioma & $6.34 \mathrm{E}-08$ & $\begin{array}{l}\text { EGFR, AKT1, NRAS, MAPK1, CDKN2A, } \\
\text { KRAS, TP53, PIK3CA, RB1 }\end{array}$ & $6.78 \mathrm{E}-05$ \\
\hline $\begin{array}{l}\text { PANTHER } \\
\text { PATHWAY }\end{array}$ & $\begin{array}{l}\text { P04398: p53 pathway } \\
\text { feedback loops } 2\end{array}$ & $2.17 \mathrm{E}-07$ & $\begin{array}{l}\text { AKT1, NRAS, CDKN2A, KRAS, MAPK14, } \\
\text { TP53, PIK3CA, RB1, TP73 }\end{array}$ & $1.98 \mathrm{E}-04$ \\
\hline $\begin{array}{l}\text { KEGG_PAT } \\
\text { HWAY }\end{array}$ & $\begin{array}{l}\text { hsa05213: Endometri } \\
\text { al cancer }\end{array}$ & $3.04 \mathrm{E}-07$ & $\begin{array}{l}\text { EGFR, AKT1, NRAS, MAPK1, KRAS, TP53, } \\
\text { PIK3CA, CDH1 }\end{array}$ & $3.25 \mathrm{E}-04$ \\
\hline $\begin{array}{l}\text { KEGG_PAT } \\
\text { HWAY }\end{array}$ & $\begin{array}{l}\text { hsa05210: Colorectal } \\
\text { cancer }\end{array}$ & $6.20 \mathrm{E}-07$ & $\begin{array}{l}\text { EGFR, AKT1, MAPK1, KRAS, MET, TP53, } \\
\text { PIK3CA, BIRC5, TGFB1 }\end{array}$ & $6.62 \mathrm{E}-04$ \\
\hline $\begin{array}{l}\text { KEGG_PAT } \\
\text { HWAY }\end{array}$ & $\begin{array}{l}\text { hsa05221:Acute } \\
\text { myeloid leukemia }\end{array}$ & $6.57 \mathrm{E}-07$ & $\begin{array}{l}\text { CEBPA, AKT1, NRAS, MAPK1, KRAS, } \\
\text { STAT5A, PIK3CA, NFKB1 }\end{array}$ & 7.01E-04 \\
\hline $\begin{array}{l}\text { KEGG_PAT } \\
\text { HWAY }\end{array}$ & $\begin{array}{l}\text { hsa05215: Prostate } \\
\text { cancer }\end{array}$ & $9.71 \mathrm{E}-07$ & $\begin{array}{l}\text { EGFR, AKT1, NRAS, MAPK1, KRAS, TP53, } \\
\text { PIK3CA, NFKB1, RB1 }\end{array}$ & 0.001037757 \\
\hline $\begin{array}{l}\text { KEGG_PAT } \\
\text { HWAY }\end{array}$ & $\begin{array}{l}\text { hsa04722: Neurotrop } \\
\text { hin signaling pathway }\end{array}$ & $1.17 \mathrm{E}-06$ & $\begin{array}{l}\text { AKT1, NRAS, MAPK1, BDNF, KRAS, } \\
\text { MAPK14, TP53, PIK3CA, NFKB1, TP73 }\end{array}$ & 0.00125362 \\
\hline $\begin{array}{l}\text { KEGG_PAT } \\
\text { HWAY }\end{array}$ & $\begin{array}{l}\text { hsa04010:MAPK } \\
\text { signaling pathway }\end{array}$ & $2.69 \mathrm{E}-06$ & $\begin{array}{l}\text { EGFR, AKT1, MAPK1, NRAS, BDNF, KRAS, } \\
\text { ARRB2, MAPK14, GADD45G, TP53, NFKB1, } \\
\text { TGFB1, RASA1 }\end{array}$ & 0.002871532 \\
\hline BIOCARTA & $\begin{array}{l}\text { h_erythPathway:Eryt } \\
\text { hrocyte } \\
\text { Differentiation } \\
\text { Pathway }\end{array}$ & $3.22 \mathrm{E}-06$ & IL3, IL6, IL9, KITLG, TGFB1, EPO & 0.003887971 \\
\hline $\begin{array}{l}\text { REACTOME } \\
\text { _PATHWAY }\end{array}$ & $\begin{array}{l}\text { REACT_16888: Signa } \\
\text { ling by PDGF }\end{array}$ & $9.59 E-06$ & $\begin{array}{l}\text { NRAS, MAPK1, KRAS, STAT5A, PIK3CA, } \\
\text { THBS1, RASA1 }\end{array}$ & 0.007693883 \\
\hline $\begin{array}{l}\text { PANTHER } \\
\text { PATHWAY }\end{array}$ & $\begin{array}{l}\text { P00056:VEGF } \\
\text { signaling pathway }\end{array}$ & $1.68 \mathrm{E}-05$ & $\begin{array}{l}\text { AKT1, NRAS, MAPK1, HIF1A, KRAS, } \\
\text { MAPK14, VEGFA, PIK3CA }\end{array}$ & 0.015328038 \\
\hline $\begin{array}{l}\text { EC_NUMBE } \\
R\end{array}$ & 3.4 .21 .59 & 4.75E-05 & TPSAB1, TPSB2, TPSD1, TPSG1 & 0.030526793 \\
\hline $\begin{array}{l}\text { KEGG_PAT } \\
\text { HWAY }\end{array}$ & $\begin{array}{l}\text { hsa04370:VEGF } \\
\text { signaling pathway }\end{array}$ & 4.94E-05 & $\begin{array}{l}\text { AKT1, NRAS, MAPK1, KRAS, MAPK } 14, \\
\text { VEGFA, PIK3CA }\end{array}$ & 0.052708911 \\
\hline $\begin{array}{l}\text { REACTOME } \\
\text { _PATHWAY }\end{array}$ & $\begin{array}{l}\text { REACT_11061:Signa } \\
\text { lling by NGF }\end{array}$ & $5.63 E-05$ & $\begin{array}{l}\text { AKT1, MAG, NRAS, MAPK1, KRAS, } \\
\text { MAPK14, PIK3CA, NFKB1, SORCS3 }\end{array}$ & 0.045131702 \\
\hline $\begin{array}{l}\text { KEGG_PAT } \\
\text { HWAY }\end{array}$ & $\begin{array}{l}\text { hsa04664:Fc epsilon } \\
\text { Rl signaling pathway }\end{array}$ & $6.17 E-05$ & $\begin{array}{l}\text { AKT1, NRAS, MAPK1, IL3, KRAS, MAPK14, } \\
\text { PIK3CA }\end{array}$ & 0.065876411 \\
\hline $\begin{array}{l}\text { KEGG_PAT } \\
\text { HWAY }\end{array}$ & $\begin{array}{l}\text { hsa04150:mTOR } \\
\text { signaling pathway }\end{array}$ & $9.18 \mathrm{E}-05$ & $\begin{array}{l}\text { AKT1, MAPK1, HIF1A, STK11, VEGFA, } \\
\text { PIK3CA }\end{array}$ & 0.097993218 \\
\hline $\begin{array}{l}\text { PANTHER } \\
\text { PATHWAY }\end{array}$ & $\begin{array}{l}\text { P00005:Angiogenesi } \\
\text { s }\end{array}$ & $9.21 \mathrm{E}-05$ & $\begin{array}{l}\text { AKT1, NRAS, MAPK1, NOTCH1, HIF1A, } \\
\text { KRAS, MAPK14, VEGFA, PIK3CA, BIRC5, } \\
\text { RASA1 }\end{array}$ & 0.084242254 \\
\hline $\begin{array}{l}\text { PANTHER } \\
\text { PATHWAY }\end{array}$ & $\begin{array}{l}\text { P00018: EGF } \\
\text { receptor signaling } \\
\text { pathway }\end{array}$ & $1.11 \mathrm{E}-04$ & $\begin{array}{l}\text { EGFR, AKT1, NRAS, MAPK1, KRAS, } \\
\text { MAPK14, STAT5A, PIK3CA, RASA1 }\end{array}$ & 0.101309728 \\
\hline KEGG_PAT & hsa04012: ErbB & $1.14 \mathrm{E}-04$ & EGFR, AKT1, NRAS, MAPK1, KRAS, & 0.121813791 \\
\hline
\end{tabular}


bioRxiv preprint doi: https://doi.org/10.1101/037531; this version posted January 21, 2016. The copyright holder for this preprint (which was not certified by peer review) is the author/funder, who has granted bioRxiv a license to display the preprint in perpetuity. It is made available under aCC-BY-NC-ND 4.0 International license.

\begin{tabular}{|c|c|c|c|c|}
\hline HWAY & signaling pathway & & STAT5A, PIK3CA & \\
\hline $\begin{array}{l}\text { KEGG_PAT } \\
\text { HWAY }\end{array}$ & $\begin{array}{l}\text { hsa05216: Thyroid } \\
\text { cancer }\end{array}$ & $1.18 \mathrm{E}-04$ & NRAS, MAPK1, KRAS, TP53, CDH1 & 0.126019896 \\
\hline BIOCARTA & $\begin{array}{l}\text { h_hcmvPathway:Hu } \\
\text { man Cytomegalovirus } \\
\text { and Map Kinase } \\
\text { Pathways }\end{array}$ & $1.34 \mathrm{E}-04$ & AKT1, MAPK1, MAPK14, NFKB1, RB1 & 0.161807042 \\
\hline $\begin{array}{l}\text { KEGG_PAT } \\
\text { HWAY }\end{array}$ & $\begin{array}{l}\text { hsa04115:p53 } \\
\text { signaling pathway }\end{array}$ & $3.30 \mathrm{E}-04$ & $\begin{array}{l}\text { CDKN2A, GADD45G, RPRM, TP53, THBS1, } \\
\text { TP73 }\end{array}$ & 0.352478227 \\
\hline $\begin{array}{l}\text { KEGG_PAT } \\
\text { HWAY }\end{array}$ & $\begin{array}{l}\text { hsa04660:T cell } \\
\text { receptor signaling } \\
\text { pathway }\end{array}$ & 3.75E-04 & $\begin{array}{l}\text { AKT1, NRAS, MAPK1, KRAS, MAPK14, } \\
\text { PIK3CA, NFKB1 }\end{array}$ & 0.399792892 \\
\hline BIOCARTA & $\begin{array}{l}\text { h_telPathway:Telome } \\
\text { res, Telomerase, } \\
\text { Cellular Aging, and } \\
\text { Immortality }\end{array}$ & 3.86E-04 & EGFR, AKT1, KRAS, TP53, RB1 & 0.465899729 \\
\hline $\begin{array}{l}\text { PANTHER } \\
\text { PATHWAY }\end{array}$ & P04393: Ras Pathway & 3.87E-04 & $\begin{array}{l}\text { AKT1, NRAS, MAPK1, CDKN2A, KRAS, } \\
\text { MAPK14, PIK3CA }\end{array}$ & 0.353518988 \\
\hline $\begin{array}{l}\text { REACTOME } \\
\text { _PATHWAY }\end{array}$ & $\begin{array}{l}\text { REACT_9417:Signali } \\
\text { ng by EGFR }\end{array}$ & $5.16 \mathrm{E}-04$ & EGFR, NRAS, MAPK1, KRAS, PIK3CA & 0.413199584 \\
\hline $\begin{array}{l}\text { KEGG_PAT } \\
\text { HWAY }\end{array}$ & $\begin{array}{l}\text { hsa04662:B cell } \\
\text { receptor signaling } \\
\text { pathway }\end{array}$ & $5.22 \mathrm{E}-04$ & $\begin{array}{l}\text { AKT1, NRAS, MAPK1, KRAS, PIK3CA, } \\
\text { NFKB1 }\end{array}$ & 0.556225736 \\
\hline $\begin{array}{l}\text { KEGG_PAT } \\
\text { HWAY }\end{array}$ & $\begin{array}{l}\text { hsa05222: Small cell } \\
\text { lung cancer }\end{array}$ & 8.79E-04 & AKT1, LAMB4, TP53, PIK3CA, NFKB1, RB1 & 0.934847379 \\
\hline BIOCARTA & $\begin{array}{l}\text { h_RacCycDPathway: } \\
\text { Influence of Ras and } \\
\text { Rho proteins on G1 } \\
\text { to S Transition }\end{array}$ & 0.001228749 & AKT1, MAPK1, PIK3CA, NFKB1, RB1 & 1.475202636 \\
\hline $\begin{array}{l}\text { KEGG_PAT } \\
\text { HWAY }\end{array}$ & $\begin{array}{l}\text { hsa04320: Dorso-vent } \\
\text { ral axis formation }\end{array}$ & 0.001386389 & EGFR, MAPK1, NOTCH1, KRAS & 1.471198696 \\
\hline $\begin{array}{l}\text { REACTOME } \\
\text { _PATHWAY }\end{array}$ & $\begin{array}{l}\text { EEACT_6900:Signali } \\
\text { ng in Immune system }\end{array}$ & 0.001592713 & $\begin{array}{l}\text { MAG, NRAS, MAPK1, KRAS, CD34, } \\
\text { PECAM1, PIK3CA, NFKB1, CDH1 }\end{array}$ & 1.270531117 \\
\hline $\begin{array}{l}\text { PANTHER } \\
\text { PATHWAY }\end{array}$ & P00059:p53 pathway & 0.001789034 & $\begin{array}{l}\text { AKT1, CDKN2A, GADD45G, TP53, PIK3CA, } \\
\text { THBS1, TP73 }\end{array}$ & 1.624912242 \\
\hline $\begin{array}{l}\text { KEGG_PAT } \\
\text { HWAY }\end{array}$ & $\begin{array}{l}\text { hsa04510: Focal } \\
\text { adhesion }\end{array}$ & 0.001957264 & $\begin{array}{l}\text { EGFR, AKT1, MAPK1, LAMB4, MET, } \\
\text { VEGFA, PIK3CA, THBS1 }\end{array}$ & 2.071273278 \\
\hline $\begin{array}{l}\text { KEGG_PAT } \\
\text { HWAY }\end{array}$ & $\begin{array}{l}\text { hsa04620: Toll-like } \\
\text { receptor signaling } \\
\text { pathway }\end{array}$ & 0.002011203 & $\begin{array}{l}\text { AKT1, MAPK1, IL6, MAPK14, PIK3CA, } \\
\text { NFKB1 }\end{array}$ & 2.127799484 \\
\hline $\begin{array}{l}\text { KEGG_PAT } \\
\text { HWAY }\end{array}$ & $\begin{array}{l}\text { hsa04060: Cytokine-c } \\
\text { ytokine receptor } \\
\text { interaction }\end{array}$ & 0.002108909 & $\begin{array}{l}\text { EGFR, IL3, IL6, MET, VEGFA, IL9, KITLG, } \\
\text { TGFB1, EPO }\end{array}$ & 2.230116541 \\
\hline
\end{tabular}


bioRxiv preprint doi: https://doi.org/10.1101/037531; this version posted January 21, 2016. The copyright holder for this preprint (which was not certified by peer review) is the author/funder, who has granted bioRxiv a license to display the preprint in perpetuity. It is made available under aCC-BY-NC-ND 4.0 International license.

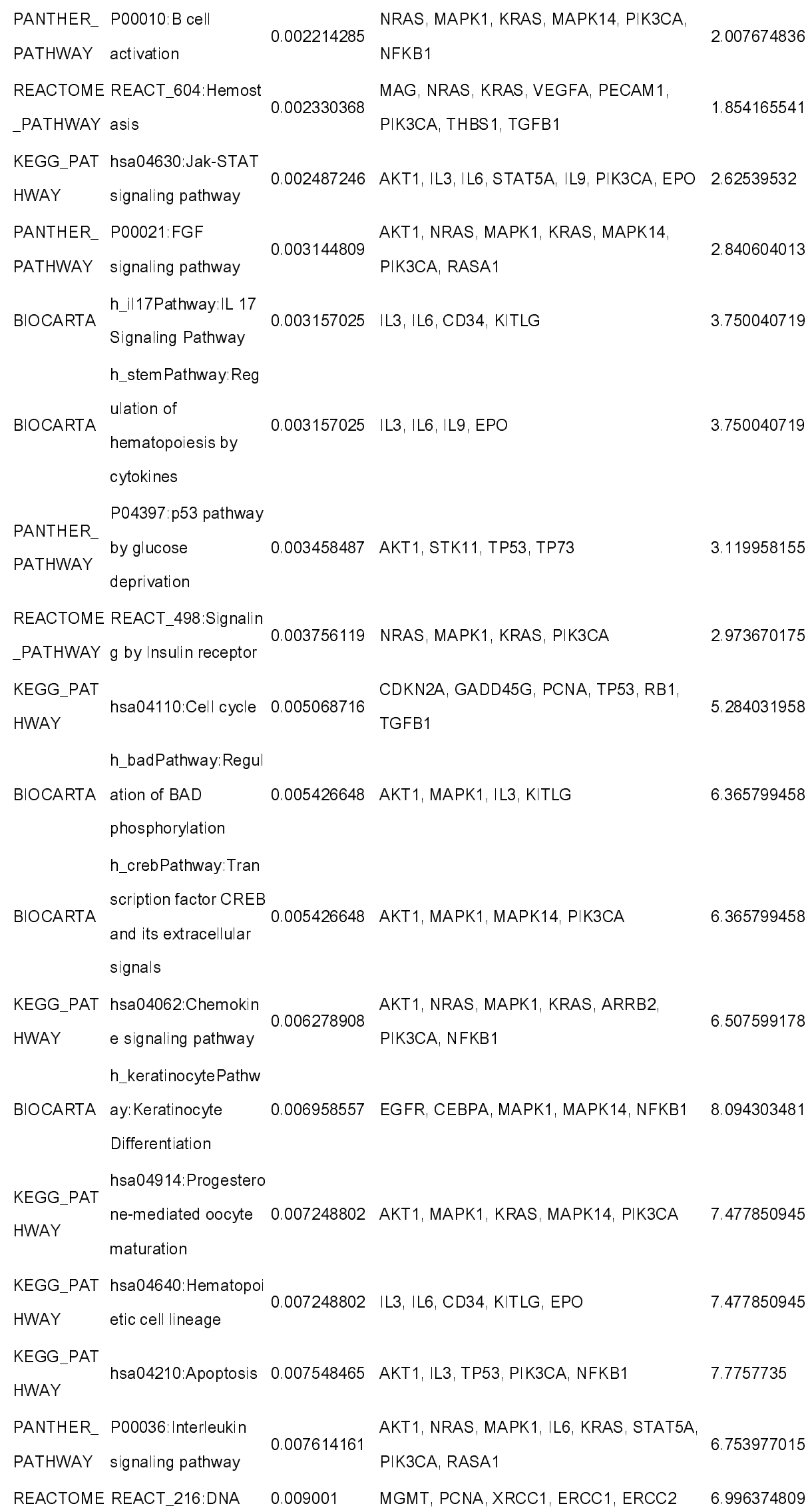




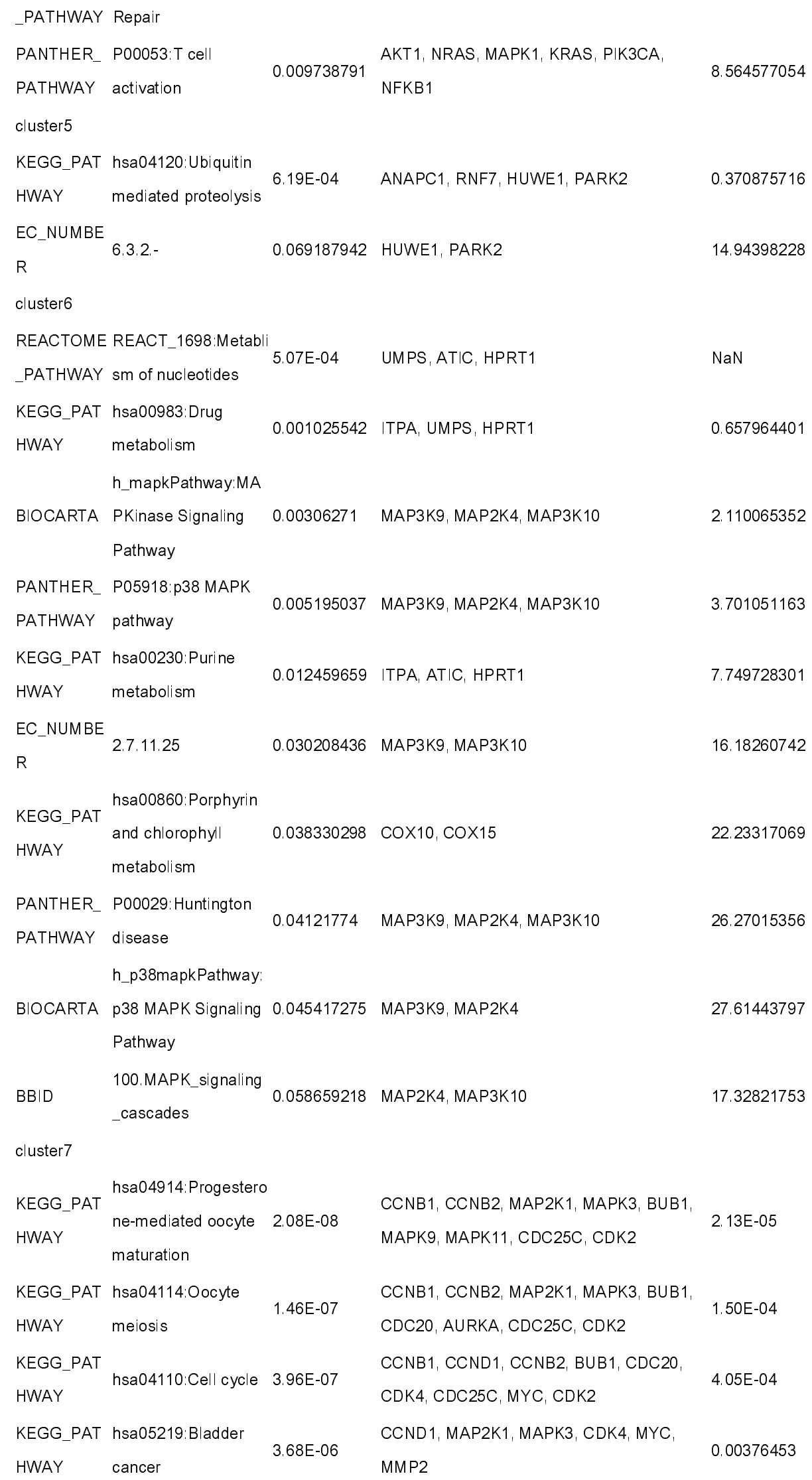




\begin{tabular}{|c|c|c|c|c|}
\hline $\begin{array}{l}\text { KEGG_PAT } \\
\text { HWAY }\end{array}$ & $\begin{array}{l}\text { hsa05210: Colorectal } \\
\text { cancer }\end{array}$ & $7.34 \mathrm{E}-06$ & $\begin{array}{l}\text { FOS, CCND1, MAP2K1, BAX, MAPK3, } \\
\text { MAPK9, MYC }\end{array}$ & 0.007502731 \\
\hline $\begin{array}{l}\text { KEGG_PAT } \\
\text { HWAY }\end{array}$ & $\begin{array}{l}\text { hsa05200: Pathways } \\
\text { in cancer }\end{array}$ & $1.02 \mathrm{E}-05$ & $\begin{array}{l}\text { FOS, CCND1, MAP2K1, BAX, MAPK3, } \\
\text { MAPK9, NFKB2, CDK4, MYC, MMP2, CDK2 }\end{array}$ & 0.010452597 \\
\hline $\begin{array}{l}\text { KEGG_PAT } \\
\text { HWAY }\end{array}$ & $\begin{array}{l}\text { hsa04010:MAPK } \\
\text { signaling pathway }\end{array}$ & $1.43 \mathrm{E}-05$ & $\begin{array}{l}\text { FOS, MAP3K5, MAP2K1, MAPK3, MAP3K8, } \\
\text { MAPK9, MAPK11, NFKB2, MAPK7, MYC }\end{array}$ & 0.014636534 \\
\hline $\begin{array}{l}\text { REACTOME } \\
\text { _PATHWAY }\end{array}$ & $\begin{array}{l}\text { REACT_152:Cell } \\
\text { Cycle, Mitotic }\end{array}$ & $1.79 \mathrm{E}-05$ & $\begin{array}{l}\text { CCNB1, CENPM, CCND1, CCNB2, BUB1, } \\
\text { CDC20, AURKA, AURKB, CDK4, CDC25C, } \\
\text { CDK2 }\end{array}$ & 0.012929573 \\
\hline $\begin{array}{l}\text { KEGG_PAT } \\
\text { HWAY }\end{array}$ & $\begin{array}{l}\text { hsa04912:GnRH } \\
\text { signaling pathway }\end{array}$ & $1.79 \mathrm{E}-05$ & $\begin{array}{l}\text { MAP2K1, MAPK3, MAPK9, MAPK11, } \\
\text { MAPK7, MMP14, MMP2 }\end{array}$ & 0.018347497 \\
\hline $\begin{array}{l}\text { EC_NUMBE } \\
R\end{array}$ & 2.7 .11 .24 & $2.02 \mathrm{E}-05$ & MAPK3, MAPK9, MAPK11, MAPK7 & 0.012135676 \\
\hline $\begin{array}{l}\text { KEGG_PAT } \\
\text { HWAY }\end{array}$ & $\begin{array}{l}\text { hsa04620: Toll-like } \\
\text { receptor signaling } \\
\text { pathway }\end{array}$ & $2.13 \mathrm{E}-05$ & $\begin{array}{l}\text { FOS, MAP2K1, MAPK3, MAP3K8, MAPK9, } \\
\text { MAPK11, TLR4 }\end{array}$ & 0.02182043 \\
\hline $\begin{array}{l}\text { PANTHER } \\
\text { PATHWAY }\end{array}$ & $\begin{array}{l}\text { P00006:Apoptosis } \\
\text { signaling pathway }\end{array}$ & $2.68 \mathrm{E}-05$ & $\begin{array}{l}\text { FOS, TNFSF10, MAP3K5, ATF3, BAX, } \\
\text { MAPK3, MAPK9, NFKB2, MAPK7 }\end{array}$ & 0.02355655 \\
\hline $\begin{array}{l}\text { KEGG_PAT } \\
\text { HWAY }\end{array}$ & $\begin{array}{l}\text { hsa04660:T cell } \\
\text { receptor signaling } \\
\text { pathway }\end{array}$ & 3.13E-05 & $\begin{array}{l}\text { FOS, MAP2K1, MAPK3, MAP3K8, MAPK9, } \\
\text { MAPK11, CDK4 }\end{array}$ & 0.032014891 \\
\hline $\begin{array}{l}\text { PANTHER } \\
\text { PATHWAY }\end{array}$ & $\begin{array}{l}\text { P00054:Toll receptor } \\
\text { signaling pathway }\end{array}$ & $3.16 \mathrm{E}-05$ & $\begin{array}{l}\text { MAP2K1, MAPK3, MAP3K8, MAPK9, } \\
\text { MAPK11, TLR4, NFKB2 }\end{array}$ & 0.02781923 \\
\hline $\begin{array}{l}\text { KEGG_PAT } \\
\text { HWAY }\end{array}$ & $\begin{array}{l}\text { hsa04115:p53 } \\
\text { signaling pathway }\end{array}$ & 4.05E-05 & $\begin{array}{l}\text { CCNB1, CCND1, CCNB2, BAX, CDK4, } \\
\text { CDK2 }\end{array}$ & 0.041438576 \\
\hline $\begin{array}{l}\text { KEGG_PAT } \\
\text { HWAY }\end{array}$ & $\begin{array}{l}\text { hsa04722: Neurotrop } \\
\text { hin signaling pathway }\end{array}$ & $6.84 \mathrm{E}-05$ & $\begin{array}{l}\text { MAP3K5, MAP2K1, BAX, MAPK3, MAPK9, } \\
\text { MAPK11, MAPK7 }\end{array}$ & 0.069959614 \\
\hline BIOCARTA & $\begin{array}{l}\text { h_mapkPathway:MA } \\
\text { PKinase Signaling } \\
\text { Pathway }\end{array}$ & $3.55 \mathrm{E}-04$ & $\begin{array}{l}\text { FOS, MAP3K5, MAP2K1, MAPK3, MAP3K8, } \\
\text { MAPK9, MAPK11, MAPK7 }\end{array}$ & 0.400316292 \\
\hline $\begin{array}{l}\text { KEGG_PAT } \\
\text { HWAY }\end{array}$ & $\begin{array}{l}\text { hsa05216: Thyroid } \\
\text { cancer }\end{array}$ & $6.11 \mathrm{E}-04$ & CCND1, MAP2K1, MAPK3, MYC & 0.622621821 \\
\hline $\begin{array}{l}\text { PANTHER } \\
\text { PATHWAY }\end{array}$ & $\begin{array}{l}\text { P00052:TGF-beta } \\
\text { signaling pathway }\end{array}$ & $6.33 \mathrm{E}-04$ & $\begin{array}{l}\text { FOS, FOXF1, FOXA1, MAPK3, MAPK9, } \\
\text { MAPK11, MAPK7, FOSL1 }\end{array}$ & 0.555596842 \\
\hline $\begin{array}{l}\text { KEGG_PAT } \\
\text { HWAY }\end{array}$ & $\begin{array}{l}\text { hsa05212: Pancreatic } \\
\text { cancer }\end{array}$ & $7.67 \mathrm{E}-04$ & CCND1, MAP2K1, MAPK3, MAPK9, CDK4 & 0.781138732 \\
\hline $\begin{array}{l}\text { KEGG_PAT } \\
\text { HWAY }\end{array}$ & $\begin{array}{l}\text { hsa05220:Chronic } \\
\text { myeloid leukemia }\end{array}$ & $8.95 \mathrm{E}-04$ & CCND1, MAP2K1, MAPK3, CDK4, MYC & 0.91105286 \\
\hline $\begin{array}{l}\text { PANTHER } \\
\text { PATHWAY }\end{array}$ & $\begin{array}{l}\text { P00010: } B \text { cell } \\
\text { activation }\end{array}$ & 0.001400729 & $\begin{array}{l}\text { FOS, MAP2K1, MAPK3, MAPK9, MAPK11, } \\
\text { NFKB2 }\end{array}$ & 1.225108429 \\
\hline BIOCARTA & $\begin{array}{l}\text { h_p53Pathway:p53 } \\
\text { Signaling Pathway }\end{array}$ & 0.003024948 & CCND1, BAX, CDK4, CDK2 & 3.364924295 \\
\hline
\end{tabular}


bioRxiv preprint doi: https://doi.org/10.1101/037531; this version posted January 21,2016 . The copyright holder for this preprint (which was not certified by peer review) is the author/funder, who has granted bioRxiv a license to display the preprint in perpetuity. It is made available under aCC-BY-NC-ND 4.0 International license.

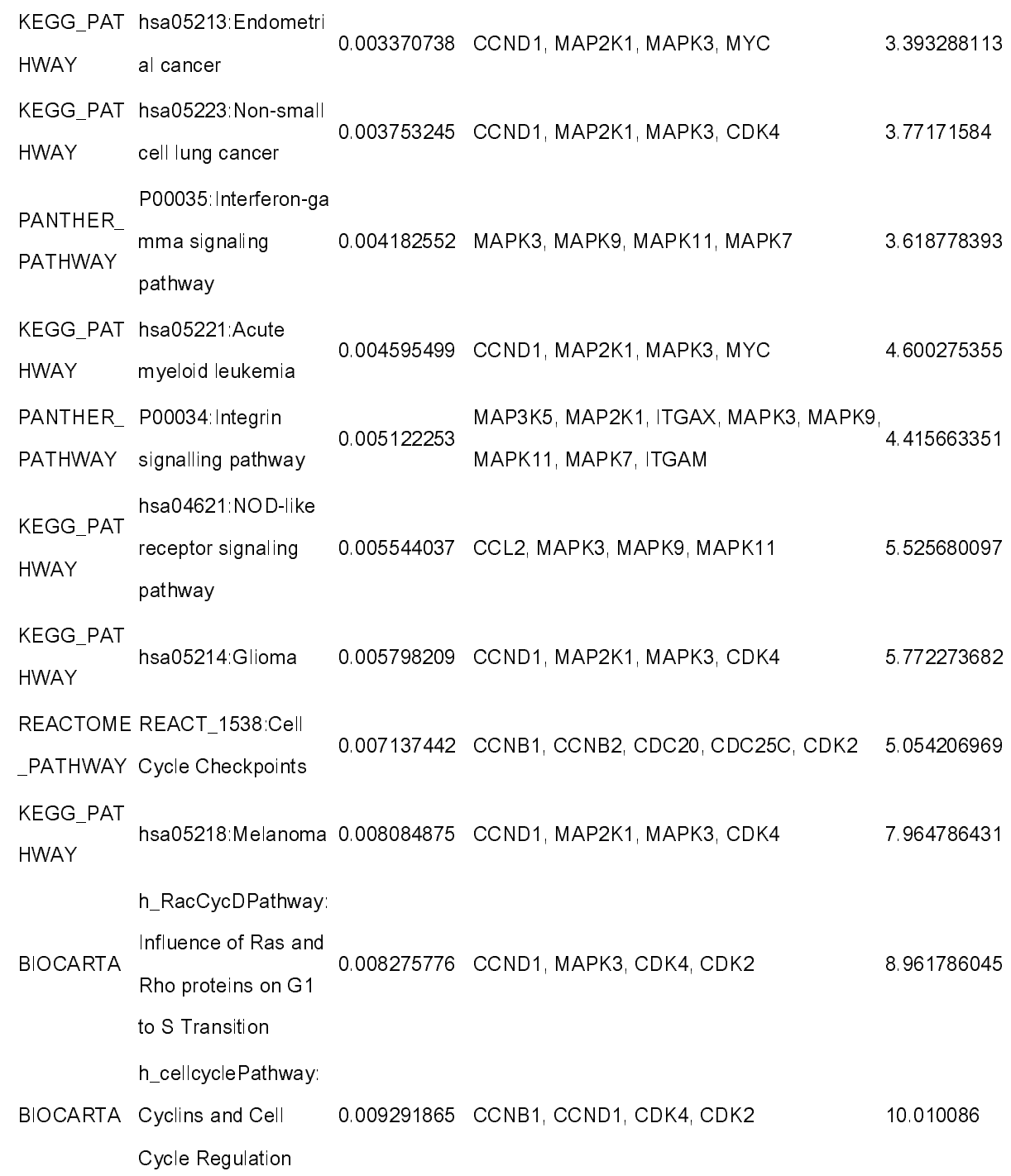

